\title{
Effects of constant and stepwise changes in temperature on the species abundance dynamics of four cladocera species
}

\author{
V.B. Verbitsky ${ }^{(1)}$, T.I. Verbitskaya ${ }^{(1)}$
}

Received December 14, 2010

Revised March 2, 2011

Accepted March 7, 2011

\section{ABSTRACT}

Key-words: temperature, ecological optimum, Cladocera, stepwise changes, prolonged effects, realized niche

\begin{abstract}
Laboratory experiments with natural zooplankton communities were carried out to study the effects of two contrasting temperature regimes: constant temperature $\left(15,20\right.$, and $\left.25^{\circ} \mathrm{C}\right)$ and graded changes in temperature. The graded regime consisted of repeated sustained (three weeks) controlled stepwise temperature changes of 5 or $10^{\circ} \mathrm{C}$ within $15-25^{\circ} \mathrm{C}$ on the population dynamics of four dominant species of lake littoral zooplankton, Daphnia longispina (Müller, 1785), Diaphanosoma brachyurum (Lievin, 1848), Simocephalus vetulus (Müller, 1776) and Chydorus sphaericus (Müller, 1785).The results show that controlled stepwise changes (positive or negative) in temperature within the ranges of $15-20,20-25$, and $15-25{ }^{\circ} \mathrm{C}$ can exert either stimulating or inhibitory effect (direct or delayed) on the development of $D$. longispina and $S$. vetulus populations. The development of $D$. brachyurum and $C h$. sphaericus, both more stenothermophile, was only stimulated by a stable elevated temperature $\left(25^{\circ} \mathrm{C}\right)$. These results support the previously formulated hypothesis that, in determining the ecological temperature optimum of a species within a natural community, it is not enough to define its optimum from constant, cyclic or random temperature fluctuations, but also from unidirectional stepwise changes in temperature. These stepwise changes may also induce prolonged or delayed effects.
\end{abstract}

RÉSUMÉ

Effets de changements graduels en température sur la dynamique de quatre espèces de cladocères

Mots-clés : température, optimum écologique, Cladocère, changements graduels, effets prolongés, niche « réalisée »
Des expériences de laboratoire sur des communautés naturelles de zooplancton ont été conduites pour étudier les effets de deux régimes contrastés de température : température constante $\left(15,20,25^{\circ} \mathrm{C}\right)$ et changements graduels de température. Le régime graduel consistait en des changements de température par paliers contrôlés (de trois semaines) de 5 ou $10{ }^{\circ} \mathrm{C}$ entre 15 et $25{ }^{\circ} \mathrm{C}$ sur des populations de quatre espèces dominantes de zooplancton littoral lacustre, Daphnia longispina (Müller, 1785), Diaphanosoma brachyurum (Lievin, 1848),Simocephalus vetulus (Müller, 1776) and Chydorus sphaericus (Müller, 1785). Les résultats montrent que les changements par paliers contrôlés (positifs ou négatifs) en température dans les gammes $15-20,20-25$ et $15-25^{\circ} \mathrm{C}$ peuvent exercer un effet soit stimulant, soit inhibiteur (immédiat ou retardé) sur le développement des populations de $D$. longispina and S. vetulus. Le développement

(1) Papanin Biological Institute of Inland Waters, Russian Academy of Sciences, Borok, 152742 Yaroslavl district, Russia,verb@ibiw.yaroslavl.ru 
de $D$. brachyurum et Ch. sphaericus, tous les deux sténo-thermophiles, était stimulé seulement par une température élevée stable $\left(25^{\circ} \mathrm{C}\right)$. Ces résultats confirment l'hypothèse formulée auparavant que, dans la détermination de l'optimum thermique d'une espèce d'une communauté naturelle, il ne suffit pas de définir son optimum à partir de températures constantes, ou de fluctuations cycliques ou aléatoires, mais aussi par des changements de température graduels. Ces changements graduels peuvent également produire des effets prolongés ou retardés.

\section{INTRODUCTION}

Temperature directly influence the rate of most biochemical processes in organisms, especially ectotherms, as well as the abiotic properties of the environment (Loiterton et al., 2004), hence it has attracted a lot of attention from ecologists (Angilletta, 2009). Species temperature optima of ectotherms have been invariably defined as the body temperature for which maximum metabolism or normal daily activities occur (Prosser and Brown, 1967; Angilletta et al., 2002, p. 250; IUPS Thermal Commission, 2003, p. 91).

The concept of "ecological optima" is comparable to the multivariate niche concept of Hutchinson (1957). Most of the research on ectotherm temperature optima has focused on individual or species specific response to temperature independently of other factors, equivalent to defining the "fundamental" niche of the species. However, in nature, the fundamental niche of the species may be displaced (to what is called the "realised" niche) in the presence of other species or different environmental conditions (Tilman et al., 1986; Kreutzer and Lampert, 1999).

Moreover it was shown in many species, that optimum values differ for different physiological functions (Dent and Lutterschmidt, 2003; Rodnick et al., 2004) and biochemical processes (Gamperl et al., 2002) in the same organism. These values also depend on ontogenetic stage (Du et al., 2007), sex (Melanie and Shine, 1999; Hernandez et al., 2002), body size (Hoelker, 2003), season of year, time of day (Svirskiy and Valtonen, 2002), satiety (Giebelhausen and Lampert, 2001) and general physiological state (Novingera and Coon, 2000). It was also shown, that rates of growth and development differ under various conditions (Fisher and Edwards, 2002).

Hence, despite the large number of experiments involving temperature, and our increasing autecological knowledge, species response to temperature changes in natural communities are often not predictable due to the complexity of the natural systems (Schiel et al., 2004).

Many studies have been devoted to research the influence of the rhythmic diurnal thermoperiods on different functions of ectothermic animals (e.g. Eubank et al., 1973; Merkel, 1977; Sweeney and Schnack, 1977; Humpesch, 1982; Joshi, 1996; Dong et al., 2006, 2008; Du et al. 2009). The influence of quickly oscillating temperatures was also investigated (Shelford, 1927; Sushchenja, 1978; Schmidt, 1981; Behrens et al., 1983). These studies modelled natural changes in temperature, where temperature usually undergoes regular diurnal variations, frequently superimposed by irregular fluctuations.

This may explain why fluctuating (astatic) temperature regimes may be more favorable to a species than constant temperature (Odum, 1971; Dajos, 1975; Meyers, 1984; Konstantinov, 1993; Konstantinov et al., 2000; reviewed in Verbitsky, 2008), although neutral or negative results have also been reported (Costlow and Bookhout, 1971; Thorp and Hoss, 1975; Sharitz and Luvall, 1978; Thorp and Wineriter, 1981; Du et al., 2009). For example, small and medium temperature fluctuations accelerated the growth of sea cucumbers (Apostichopus japonicus Selenka) while the large temperature fluctuation retarded growth (Dong et al., 2006, 2008).

While there has been a number of studies comparing the effect of constant and cyclic temperature regime on individual species metabolism, development or population dynamics (e.g. Khan, 1965; Barnes and Barnes, 1969; Sharitz and Luvall, 1978) very few have focused on 


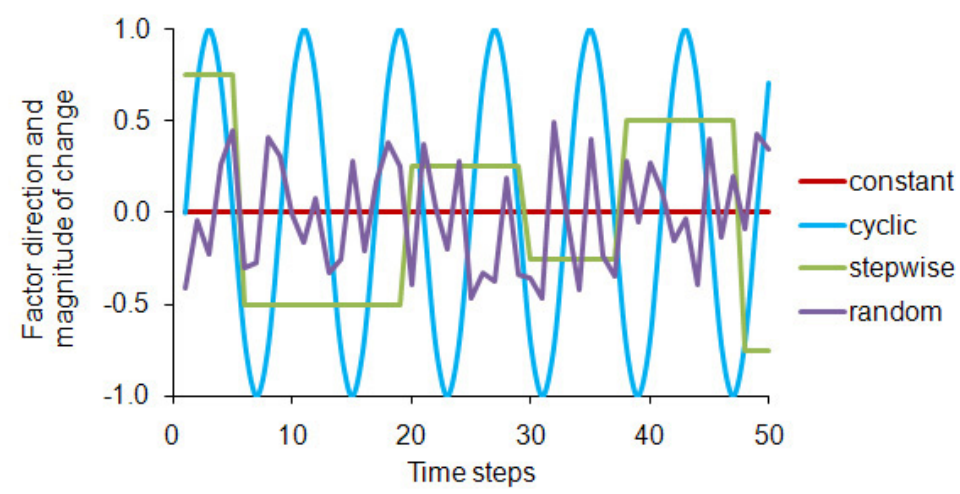

\section{Figure 1}

The variability in environmental factors may follows different regimes: cyclic, constant, stepwise, random which may be characterized by direction, magnitude, frequency, duration, timing and rate of change.

\section{Figure 1}

Les variations des facteurs environnementaux peuvent suivre différents régimes : cyclique, constant, graduel, aléatoire, qui peuvent être caractérisés par leurs direction, amplitude, fréquence, durée, rythme et taux de changement.

arrhythmic (random) temperature changes (e.g. Thorp and Wineriter, 1981), despite the fact that inhabitants of both undisturbed and thermally altered water systems may be exposed to rapid rate of change and sometimes unpredictable for individual temperature shifts.

Stepwise changes in temperature have received scant attention despite the increasing threat and occurrence of heat (or cold) waves with climate change. For example, the 2010 summer heat wave has surpassed all temperature records in Russia. Predicting the ecological response to such unpredictable change and extreme weather conditions remains a challenging task. The use of experimental microcosms may allow testing predictions of temperature changes on species, communities and ecosystem dynamics.

Hence there is a need to manipulate the temperature regimes (constant, cyclic, stepwise, random; Figure 1) as well as its characteristics (such as direction, magnitude, frequency, duration, timing and rate of change). Here the focus will be on sudden (unpredictable), sustained stepwise changes (which may resemble change in weather patterns) and study its effect on the population dynamics of species from natural communities to move towards a more predictive ecology of natural systems.

The purposes of this research were the following: (1) describe the effects of stepwise sustained (three weeks) controlled temperature shifts (relative to constant temperature controls) differing in magnitude $\left(5\right.$ or $10^{\circ} \mathrm{C}$ ) and direction (positive or negative) on the dynamics of experimental populations of freshwater zooplankton species from a natural assemblage; (2) investigate influence of the recovery period after the termination of treatment effects; and (3) on the basis of the results and previous researches, state our understanding of the concept of temperature optimum for ectotherms. The concept itself may be applied to any ecological factors (e.g. water discharge in river ecosystems, Poff and Zimmerman, 2010).

\section{MATERIAL AND METHODS}

The population responses of dominant zooplankton species to graduated temperature influences were studied in long-term experiments (lasting more than 63 days) on microcosms created in $45 \mathrm{~L}$ aquariums $(58 \times 30 \times 26 \mathrm{~cm})$. These aquariums were kept in a room open to diffuse sunlight and additionally illuminated with fluorescent lamps for $16 \mathrm{~h}$ (from 7 a.m. to 11 p.m.). Zooplankton was collected in the littoral of the Rybinsk Reservoir (the Upper Volga basin) with a $64 \mu \mathrm{m}$ mesh size net and released into aquariums so that their density was comparable to 


\section{Table I}

Experimental design: timing of controlled stepped changes in water temperature. Shaded rows are the controlled experimental variants.

Tableau I

Dispositif expérimental : rythme des changements par paliers contrôlés dans la température de l'eau. Les lignes grisées sont les expérimentations à température constante.

\begin{tabular}{|l|c|c|c|}
\hline \multirow{2}{*}{ Experimental } & \multicolumn{3}{|c|}{ Time, days } \\
\cline { 2 - 4 } & $1-21$ & $22-42$ & $43-63$ \\
\cline { 2 - 4 } & \multicolumn{3}{|c|}{ Temperature, ${ }^{\circ} \mathrm{C}$} \\
\hline $\mathbf{1}$ & 15 & 15 & 15 \\
\hline $\mathbf{2}$ & 15 & 20 & 15 \\
\hline $\mathbf{3}$ & 15 & 25 & 15 \\
\hline $\mathbf{4}$ & 20 & 20 & 20 \\
\hline $\mathbf{5}$ & 20 & 15 & 20 \\
\hline $\mathbf{6}$ & 20 & 25 & 20 \\
\hline $\mathbf{7}$ & 25 & 25 & 25 \\
\hline $\mathbf{8}$ & 25 & 15 & 25 \\
\hline $\mathbf{9}$ & 25 & 20 & 25 \\
\hline
\end{tabular}

natural assemblages. All large organisms (mainly insects and their larvae) were removed from the catch before the zooplankton was released in aquariums. Predatory species in zooplankton were limited to few individuals of Polyphemus pediculus L. Two-thirds of the water was renewed every 3-4th day, passing through a $64 \mu \mathrm{m}$ mesh size net. To create thermostatic conditions, all aquariums were placed in plastic containers filled with water in which a certain temperature regime was maintained. Water temperature in each aquarium was adjusted according to the experimental scheme by moving it to a warmer or colder container. The time of heating or cooling ranged from 3 to $6 \mathrm{~h}$, depending on the difference between the initial and final temperatures. Temperature deviations from specified values reached $\pm 0.3-1.1^{\circ} \mathrm{C}$ in some days. The aquaria were continuously aerated and kept the oxygen concentration from 7.8 to $9.7 \mathrm{mg} \mathrm{O}_{2} \cdot \mathrm{L}^{-1}$ (93.3 to $99.5 \%$ dissolved oxygen saturation).

The zooplankton was fed a suspension of Chlorella vulgaris algae, which was added during water replacement to a concentration of $1.2 \pm 0.3 \times 10^{6}$ cells $\cdot \mathrm{mL}^{-1}$. In the intervening periods, it decreased by a factor of 2.5-3 but always remained above the "threshold food concentration" (Hanasato and Yasuno, 1985). The concentration of algae in the water was estimated by measuring the optical density in a KFK-2MP spectrophotometer (655 nm wave length with a $1.7 \mathrm{~cm}$ cell; made in Russia). The optical density was previously related to Chlorella cell counts (calibration curve). Measurements were taken at the time of water renewal.

The experiment was designed so as to study the effect of stepwise change in temperature on populations of natural zooplankton depending on its direction (determined by heating or cooling the water in the microcosms) and strength (the difference between the initial and final temperatures). It generally takes 1.5-2.5 weeks after the transfer from natural biotopes to microcosms for the acclimation of zooplankton where a structural reorganization of the community occurs. Hence, no manipulations were performed during the first 21 days. Three controls were set with constant water temperatures of $15^{\circ} \mathrm{C}$ (control 1), $20{ }^{\circ} \mathrm{C}$ (control 4) and $25{ }^{\circ} \mathrm{C}$ (control 7). In experimental treatments, the water was heated by 5 or $10^{\circ} \mathrm{C}$ relative to control 1 , cooled by 5 or $10^{\circ} \mathrm{C}$ relative to control 7 , and cooled or heated by $5{ }^{\circ} \mathrm{C}$ relative to control 4. The controlled stepped change in temperature was maintained for three weeks (day 22 to 42). Thereafter, the temperature was adjusted to the initial values and maintained for another three weeks (day 43-63). Every experimental variants (controls and treatments) were replicated three times. The details of the manipulations are summarized in Table I.

Quantitative zooplankton samples (a total of 514) were taken at 3-4 day intervals. Each 1-L sample was concentrated to $10 \mathrm{~mL}$, fixed with $4 \%$ formaldehyde solution, and processed according to standard methods (Kiselyov, 1969, including examination in Bogorov's chamber 

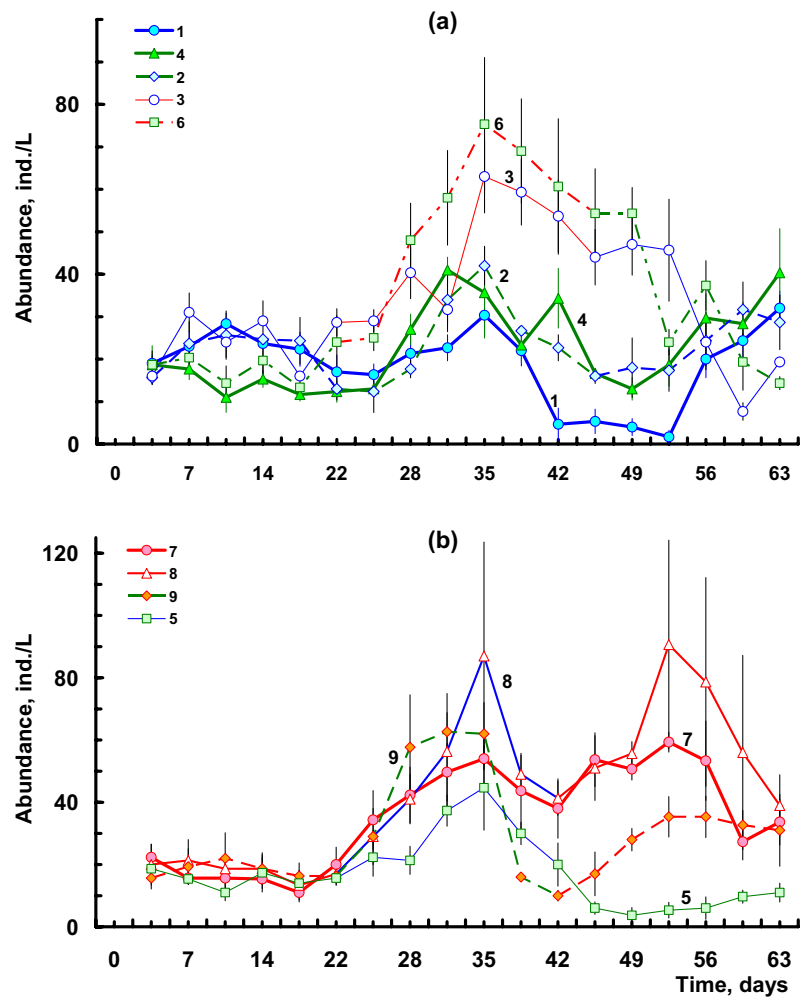

\section{Figure 2}

Dynamic of Daphnia longispina abundance in different experimental variants: (a) variants 1-5, (b) variants 6-9. 1 - Control variant with constant water temperature of $15{ }^{\circ} \mathrm{C} ; 2$ - variant, where the water was heated by $5{ }^{\circ} \mathrm{C}$ relative to control 1; 3 - variant, where the water was heated by $10{ }^{\circ} \mathrm{C}$ relative to control 1; 4-control variant with constant water temperature of $20^{\circ} \mathrm{C}$; 5 - variant, where the water was cooled by $5{ }^{\circ} \mathrm{C}$ relative to control $4 ; 6$ - variant, where the water was heated by $5{ }^{\circ} \mathrm{C}$ relative to control 4 ; 7 - control variant with constant water temperature of $25^{\circ} \mathrm{C}, 8$ - variant, where the water was cooled by $5{ }^{\circ} \mathrm{C}$ relative to control 7; 9 - variant, where the water was cooled by $10^{\circ} \mathrm{C}$ relative to control 7 .

\section{Figure 2}

Dynamique de l'abondance de Daphnia longispina dans différentes expérimentations: (a) expériences 1-5, (b) expériences 6-9. Voir le tableau I pour les régimes thermiques de chaque expérience.

under a Cytovol dissecting microscope (Carl Zeiss, Germany) to determine the species and abundance of zooplankton. Small organisms were identified under an Amplival microscope (Carl Zeiss).

Means and standard deviations (uncertainties reported throughout the manuscript) were calculated with Statistica 8 and figures were drawn in Microsoft Office Excel 6.

\section{RESULTS}

\section{> DAPHNIA LONGISPINA}

Under constant temperature, Daphnia populations were more abundant at high temperatures (Figures 2a and 2b). The dynamic of Daphnia during the first 42 days was identical during the periods of increase and decrease in abundance at all three constant temperature regimes (variants 1, 4 and 7). But greater abundance was achieved at higher temperature. Daphnia's dynamic was still the same from day 43 to 63 at constant 15 and $20^{\circ} \mathrm{C}$, but not at at $25^{\circ} \mathrm{C}$ where the period of high abundance was on average 20 days longer, than at 15 and $20^{\circ} \mathrm{C}$. At the end of the experiment (day 63), the average abundance of Daphnia in all variants, irrespective of temperature, practically returned to the initial level, with differences from it or between variants lacking statistical significance. 

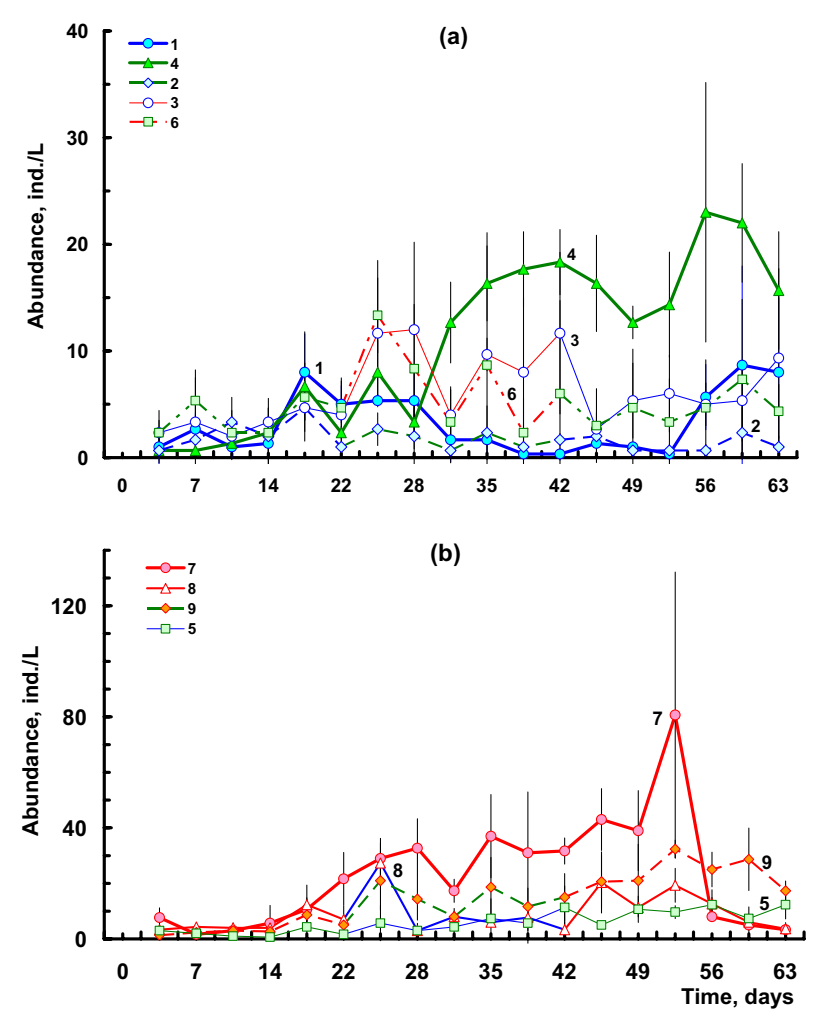

\section{Figure 3}

Dynamic of Diaphanosoma brachyurum abundance in different experimental variants (1-9). All symbols as in Figure 2.

\section{Figure 3}

Dynamique de Diaphanosoma brachyurum dans les différentes expériences (1-9). Mêmes symboles qu'en figure 2.

The pattern of abundance dynamics after water heating from 15 to $20^{\circ} \mathrm{C}$ became similar to that in the control with a constant temperature of $20^{\circ} \mathrm{C}$ (Figure 2a). Conversely, temperature drop from 20 to $15{ }^{\circ} \mathrm{C}$ resulted in a decrease in abundance to the level observed in control with a constant temperature of $15^{\circ} \mathrm{C}$. Water heating from 20 to $25^{\circ} \mathrm{C}$ had a significant stimulating effect on Daphnia (Figure 2b). After reversing the temperature regime (from 25 to $20^{\circ} \mathrm{C}$ ), their abundance remained high for ten more days and only then decreased to the level recorded in control with a constant temperature of $20^{\circ} \mathrm{C}$; i.e., a delayed stimulating effect was observed. Water cooling from 25 to $20^{\circ} \mathrm{C}$ stimulated population growth in the first 14 days Figure $2 \mathrm{~b}$ ). Both heating and cooling of water by $10^{\circ} \mathrm{C}$ proved to have a strong stimulating effect on Daphnia populations (their average abundance was twice higher than in control with a constant elevated temperature), but the effect of heating lasted longer (11 days) (Figures 2a and $2 b)$.

Thus the reactions of eurythermic Daphnia are labile and depend both on the force and direction of temperature influences. Stepwise temperature shifts in the ranges of 15-20, 20-25, and $15-25^{\circ} \mathrm{C}$, can exert both direct or extended stimulating effect and direct inhibitory effect on natural $D$. longispina populations.

\section{> DIAPHANOSOMA BRACHIURUM}

At $15{ }^{\circ} \mathrm{C}$, Diaphanosoma abundance fluctuated at a low level during the whole observation period. At $20^{\circ} \mathrm{C}$, the abundance gradually increased during the first $35-40$ days and subsequently stabilized at a level $15-23$ ind. L ${ }^{-1}$ (Figure 3a). Under constant temperature, $25{ }^{\circ} \mathrm{C}$ 

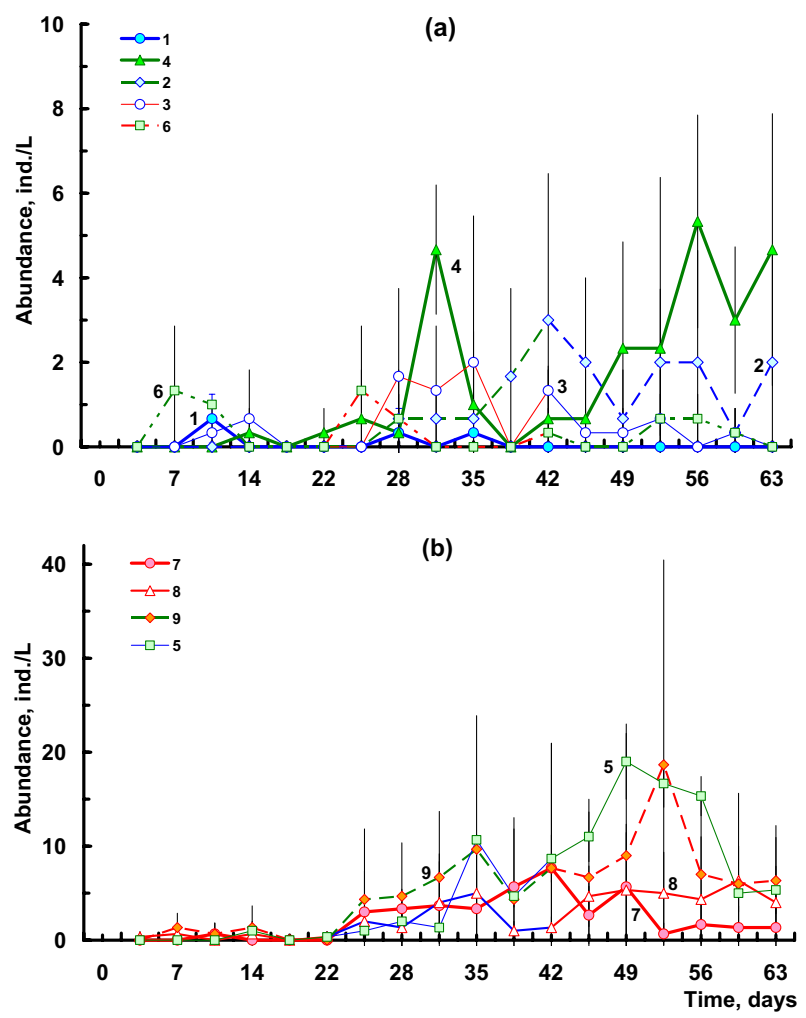

Figure 4

Dynamic of Simocephalus vetulus abundance in different experimental variants (1-9). All symbols as in Figure 2.

\section{Figure 4}

Dynamique de Simocephalus vetulus dans les différentes expériences (1-9). Mêmes symboles qu'en figure 2.

proved to be optimal for Diaphanosoma (Figure 3b). In this variant the abundance increased till day 53 , having achieved 81 ind. $\mathrm{L}^{-1}$ then sharply declined by 10 times.

Water heating from 15 to $20{ }^{\circ} \mathrm{C}$ resulted in suppressed population development (Figure 3a). Apparently, both direct and delayed inhibitory effects took place in this case. Water cooling from 20 to $15{ }^{\circ} \mathrm{C}$ also caused a significant decrease in abundance (compared to that at a constant temperature regime) (Figure 3a). Water heating from 20 to $25{ }^{\circ} \mathrm{C}$ and cooling from 25 to $20{ }^{\circ} \mathrm{C}$ retarded the growth of experimental populations (Figure 3b). In both of these treatments, a reverse temperature shift also had no effect on the pattern of abundance dynamics. Water heating by $10^{\circ} \mathrm{C}$ had a slight stimulating effect on population development in the period between days 25 and 53 (Figure 3a). Water cooling by $10^{\circ} \mathrm{C}$ retarded the growth of experimental populations by a factor of two to eight (Figure 3b).

Therefore, Diaphanosoma reached a peak of development only at a constant elevated temperature, with their abundance in all treatments being significantly lower. Alternating regimes inhibited population development, compared to that at constant regimes, and this effect manifested itself both during and after exposure.

\section{> SIMOCEPHALUS VETULUS}

Under stable temperature, at $15^{\circ} \mathrm{C}$, the abundance of cladocerans remained at the initial minimal level throughout the experiment (Figure 4a). At 20 and $25^{\circ} \mathrm{C}$, non periodic fluctuations were observed in the range 1 to $5-8$ individuals. $\mathrm{L}^{-1}$.

When the temperature was increased from 15 to $20^{\circ} \mathrm{C}$, the dynamics of Simocephalus abundance became similar to the abundance of the control with constant $20{ }^{\circ} \mathrm{C}$ temperature 

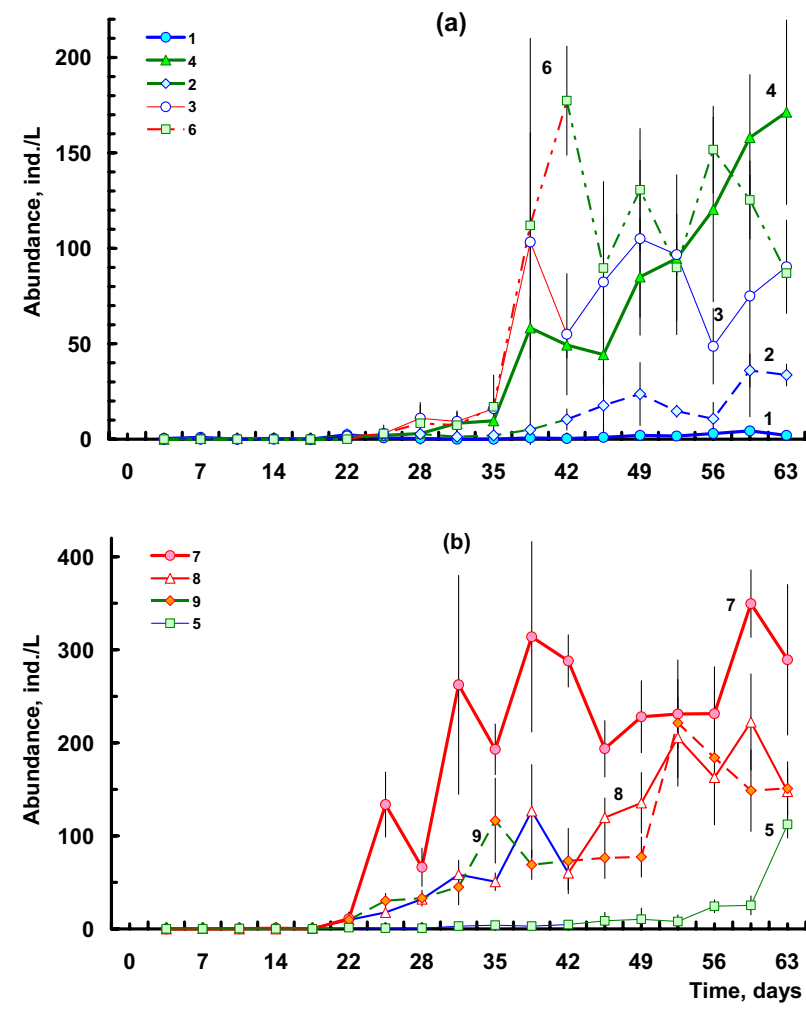

Figure 5

Dynamic of Chydorus sphaericus abundance in different experimental variants (1-9). All symbols as in Figure 2.

\section{Figure 5}

Dynamique de Chydorus sphaericus dans les différentes expériences (1-9). Mêmes symboles qu'en figure 2 .

(Figure 4a). A decrease in water temperature from 20 to $15^{\circ} \mathrm{C}$ also induced an increase in abundance, which continued to grow after the temperature increased back on day 42 , hence a a prolonged stimulatory influence was observed (Figure 4b). The heating of water from 20 to $25{ }^{\circ} \mathrm{C}$ inhibited the increase in the population abundance for a prolonged period (Figure 4a). The chilling of water by $5{ }^{\circ} \mathrm{C}$ caused a rapid increase in the population abundance (Figure $4 \mathrm{~b}$ ). The heating of water by $10^{\circ} \mathrm{C}$ caused a slight increase in the population abundance (Figure 4a). After the temperature regime was changed back, the abundance reduced again to the initial minimal level. The mean abundance of the crustaceans after the chilling of water by $10^{\circ} \mathrm{C}$ did not significantly differ from the abundance in the $25^{\circ} \mathrm{C}$ control because of large uncertainties (Figure 4b).

Thus the maximum development of Simocephalus populations was observed when the water temperature decreased from 25 to $20^{\circ} \mathrm{C}$ and from 20 to $15{ }^{\circ} \mathrm{C}$. In those treatments, a prolonged stimulatory effect of temperature change was observed on the abundance of Simocephalus.

\section{> CHYDORUS SPHAERICUS}

Abundance of Chydorus under stable temperature regimes displayed higher abundance at higher temperature. This species reached the maximal development at $25{ }^{\circ} \mathrm{C}$ (Figures $5 \mathrm{a}$ and $5 \mathrm{~b}$ ). Thus at $20^{\circ} \mathrm{C}$ the abundance increased continuously up to the end of experiment achieving 171 ind. $\mathrm{L}^{-1}$. At $25^{\circ} \mathrm{C}$ the abundance increased up to day 32 , then fluctuated up to the end of the experiment at $194-350 \mathrm{ind} \cdot \mathrm{L}^{-1}$. 
Abundance of Chydorus generally tracked the controlled and sustained changes in temperature (Figures $5 \mathrm{a}$ and $5 b$ ).

\section{DISCUSSION}

Daphnia longispina is a dominant species in the littoral zone of the Rybinsk reservoir. This species becomes highly abundant at temperatures above $14{ }^{\circ} \mathrm{C}$ but disappears from the plankton after water warming up to $25.8^{\circ} \mathrm{C}$ (Verbitsky et al., 2002). The results of this study agree with published data on $D$. longispina development in natural biotopes. It is known that $D$. longispina actively develops both in summer and in winter, it is noteworthy that it has proved to dominate in years with low summer temperatures in the Rybinsk Reservoir (Rivjer, 1986, 1992) and in winter and spring months in the Azibo Reservoir, Portugal (Geraldes and Boavida, 2004). At temperatures above $26^{\circ} \mathrm{C}$ (e.g., in zones of heated water discharge from thermal power plants), the species disappears from the plankton (Elagina, 1974). Many authors have also shown that the actual growth rates of Daphnia species are higher at alternating temperatures than at comparable average constant temperatures (Orcutt and Porter, 1983; Manca et al., 1986). The range of most favorable temperatures for $D$. longispina is $15-21^{\circ} \mathrm{C}$, and the specific growth rate of these crustaceans at constant population density does not depend on temperature within this range (Sarviro, 1985). According to Hanasato and Yasuno (1985), even-sized newborn Daphnia raised at 15,20 and $25^{\circ} \mathrm{C}$ show no differences in body length after 25 days, and their growth curves at these temperatures are also similar. These authors have also found Daphnia in the hypolimnion of Lake lunoko (Japan) at a water temperature of $12{ }^{\circ} \mathrm{C}$. On this basis, they conclude that $D$. longispina is adapted to life at relatively low temperatures. Some reports (McKee et al., 2003) that population abundances of large bodied cladocerans, $D$. longispina and $S$. vetulus from microcosm ecosystems created to mimic shallow pond environments, were practically not affected by the $3^{\circ} \mathrm{C}$ increase in temperature above ambient natural temperature.

All these results agree well with the data described above. In almost all experimental regimes with the water temperature changing within the range of $15-25^{\circ} \mathrm{C}$, the first stepwise shift by 5 or $10{ }^{\circ} \mathrm{C}$, either upward or downward, stimulated the development of $D$. longispina populations. The only exception was the variant with water cooling from 20 to $15^{\circ} \mathrm{C}$, which proved to have no effect on the pattern of abundance dynamics.

A similar effect was described for strains of infusorians Blepharisma collected in various latitudinal zones and subsequently kept at $20{ }^{\circ} \mathrm{C}$ for a long period of time (Hinz and Isquith, 1974). The growth rate of these infusorians increased after temperature was raised shortly up to 30 and $40{ }^{\circ} \mathrm{C}$ and then returned to $20^{\circ} \mathrm{C}$. Also, the ambient temperature during embryogenesis in rotifers Brachionus calyciflorus Pallas (Galkovskaja et al., 1988) and Cladocera Daphnia magna Straus exerts a so-called "trace" effect on growth parameters during the postembryonic period. It should be noted, however, that under constant temperature conditions within the range of $15-25^{\circ} \mathrm{C}$, the abundance of $D$. longispina has proved to increase at higher temperatures. Thus fluctuations in abundance occurred in variants with constant regimes also there were the fluctuations of an abundance during similar periods to other variants. It is interesting, that the maximal values and cyclicity of abundance at constant temperatures were equal to those recorded in water reservoirs (e.g. Ranta and Tjossem, 1987; Manca and Comoli, 1999). The similar limits in abundance between experiments and water reservoir may suggest internal population mechanisms of abundance regulation, although a more complex regulation (interaction of top-down and bottom-up controls) in the natural environment cannot be ruled out.

\section{> DIAPHANOSOMA BRACHYURUM}

The fact that experimental populations of this species could reach the maximum level of development only at elevated temperatures is in agreement with numerous published data on its development in water bodies, which characterize $D$. brachyurum as a stenothermic thermophile (Herzig, 1984; Bertilsson et al., 1995; etc.). Eie (1974) recorded this species only in 
lakes located in climatic zones with relatively long and warm summers. The development of these cladocerans in the mesoeutrophic Azibo Reservoir was also observed only in the summer period (Geraldes and Boavida, 2004). Gulyas (1980) estimated the temperature optimum for this species at $19-22{ }^{\circ} \mathrm{C}$, since he could find the first mature females only when the average water temperature exceeded $19.3^{\circ} \mathrm{C}$. In autumn, when it dropped to $15^{\circ} \mathrm{C}$, the abundance of parthenogenetic females decreased rapidly, and they disappeared from the plankton at $10-11^{\circ} \mathrm{C}$. Hanazato and Yasuno (1985) found that the growth rate of $D$. brachyurum remained unchanged within a temperature range of $20-30{ }^{\circ} \mathrm{C}$ but decreased significantly at lower temperatures between 15 and $20^{\circ} \mathrm{C}$. In the zone of heated water discharge from the Kostroma thermal power plant, an abundant development of $D$. brachyurum began only after the water temperature had reached $30^{\circ} \mathrm{C}$, sometimes even rising to $34.8^{\circ} \mathrm{C}$ (Elagina, 1974). The results of experimental studies on several prevalent zooplankton species show that $D$. brachyurum is the least competitive among them (Semenchenko et al., 2005). It can reach a high abundance only at a very high equilibrium concentration of food and has a low rate of population growth. After comparing our experimental data with field observations and the results of comparative studies on the competitiveness of $D$. brachyurum, it becomes evident why this species in water bodies is usually no more than subdominant even under the most favorable nutrient and thermal conditions.

\section{> SIMOCEPHALUS VETULUS}

It is a typical littoral, shallow, phytophilous species, inhabiting overgrown vegetated littoral lakes and reservoirs, and also temporary reservoirs in which significant differences of temperatures, even dayly, occur (Bertilsson et al., 1995; Hann and Zrum, 1997; Stansfield et al., 1997). From our data, along the littoral of the Rybinsk reservoir, in spring, S. vetulus develops at temperatures above $14-16{ }^{\circ} \mathrm{C}$, and the peak of abundance is during the summer months with temperatures reaching $20-25^{\circ} \mathrm{C}$.

According to our data, Bosmina longirostris (Müller, 1785) is the first Cladocera to increase in abundance in spring, in the littoral of the Rybinsk reservoir, when water warms up to $6-8{ }^{\circ} \mathrm{C}$ (personal observation). Upon further warming to $10-12{ }^{\circ} \mathrm{C}$, the number of other species increases: Daphnia longispina (Müller, 1785), Ceriodaphnia quadrangula (Müller, 1785), Diaphanosoma brachyurum (Lievin), predatory Polyphemus pediculus (L.), Chydorus sphaericus (Müller, 1785), Acroperus harpae (Baird), Alona sp., and other species. The development of Simocephalus vetulus starts at temperatures of $>14-16{ }^{\circ} \mathrm{C}$, peaking in summer at temperatures of $20-25^{\circ} \mathrm{C}$. According to van Doorslaer et al. (2007), the optimal temperature for $\mathrm{S}$. vetulus is $22{ }^{\circ} \mathrm{C}$; the stressful temperature is $26{ }^{\circ} \mathrm{C}$. Unlike most species listed above, S. vetulus does not exhibit short unimodal or bimodal peaks in number. This species is a constant subdominant species.

The analysis of the abundance dynamic of Diaphanosoma birgei (Korinek); Ceriodaphnia dubia Richard, 1994; Pleuroxus denticulatus Birge, 1970; Chydorus sp.; and Simocephalus vetulus in (Hann and Zrum, 1997) also demonstrates the presence in all species, except for the latter, of several (one to three) short peaks of development in three summer months; in S. vetulus, the high number period continues from the beginning of June to mid July. Other researchers report on similar dynamic patterns (Perrow et al., 1999; Balayla and Moss, 2003). There are no published data indicating that, upon changes in water temperature, the water cooling periods particularly stimulate number growth in $S$. vetulus, as was found in this study. Presumably, in natural conditions, due to the high variability of the temperature simultaneously with other factors, it is difficult to find cause and effect relationships for such interactions.

Natural populations of $S$. vetulus should develop well at water temperatures $>15{ }^{\circ} \mathrm{C}$ both at relatively stable and fluctuating temperature regimes and at sharp and strong changes in temperature. The astatic regime should be more favorable for their development than the stable regime, especially after a $4-4.5^{\circ} \mathrm{C}$ decrease in temperature.

In addition to high thermal lability, $S$. vetulus possesses a relatively high oxygen lability (LaBerge and Hann, 1990) and feeding plasticity, which is confirmed by the high growth rates 
of populations even at very low equilibrium concentrations of food, which results in a decrease in number being observed in other species (Semenchenko et al., 2005, 2007). Moreover, upon changes in the water temperature within the diapason of $12-25^{\circ} \mathrm{C} \mathrm{S}$. vetulus is able to recover its carbon assimilation rate quickly (Bevan et al., 1980), which, as the authors of this paper believe, indicates the ability of this species to quickly acclimate at various temperatures.

The thermo-lability of $S$. vetulus coupled with high general ecological plasticity explain the successful coexistence of this species with other littoral species of zooplankton throughout the growing season in most water bodies with temperate climate.

\section{> CHYDORUS SPHAERICUS}

C. sphaericus is known as a particularly tolerant species, being able to thrive in a wide range of conditions, and to have a fairly ubiquitous distribution (Duigan, 1992; Fryer, 1993). In water reservoirs, the eurybiontic species $C h$. sphaericus occurs over a very wide temperature range: from $2-4{ }^{\circ} \mathrm{C}$ in the ice period, where feeding but not reproduction occurs (Rivjer, 1986, 1992), to $36{ }^{\circ} \mathrm{C}$ in cooling ponds from thermal discharges (Gorobey, 1974). Moreover, massive development of this species has been recorded in the heated zone of the cooling pond of power stations observed in the period of maximum summer temperatures (Velichko, 1982). An earlier study from the same water body noted the almost complete absence of this species in cold years and the massive development in the warm years (Luferova and Monakov, 1966).

The success of $C$. sphaericus has been attributed to factors such as its physiological tolerance, its evasion of predation because of its spherical carapace and an ability to assume a planktonic lifestyle, possibly using mats or filaments of algae as its substratum (Fryer, $1968,1993)$. These factors may also explain a reported dominance of $C$. sphaericus in nutrient enriched water bodies (Whiteside and Harmsworth, 1967; Hofmann, 1996; Mezquita and Miracle, 1997).

The responses of three chydorid species, C. sphaericus (Müller), Alona affinis (Leydig) and Alonopsis elongata (Sars) to temperature, $\mathrm{pH}$ and food type were previously examined (Eyto and Irvine, 2001). C. sphaericus had the fastest egg development time at all temperatures $\left(8,12,16\right.$ or $\left.20^{\circ} \mathrm{C}\right)$, at all $\mathrm{pH}$ levels $(5.0,6.6,8.4)$ and on all versions of food (algae Chlamydomonas reinhardi, detritus and filtered pond water containing only microorganisms $<30 \mu \mathrm{m}$ ). This is consistent to other studies that found similar egg development times of $C$. sphaericus (Bottrell, 1974; Meyers, 1984).

The universal presence of this species is also provided by its population ability to grow at a faster rate than the other species when fed on an algal culture and on filtered pond water, suggesting that in addition to using algal mats as a substratum on which to live (Fryer, 1968; Havens, 1991), it is also able to feed on bacteria and tiny detritus particles $(<30 \mu \mathrm{m})$ (Fryer, 1968). C. sphaericus is also particularly successful in nutrient enriched lakes with high phytoplankton biomass (Whiteside, 1970).

Hence, we experimentally has shown, that the abundance of Cladocera species may be stimulated not only by warming or rhythmic oscillatory regimes (as previously reported), but also by unidirectional stepwise changes in temperature (sudden heating or cooling of water).

Thus, the investigated four species can be divided into two groups based on the characteristics of their response to temperature: (1) D. longispina and S. vetulus populations which achieve maximal abundance in variable temperature regimes; and (2) D. brachyurum and C. sphaericus populations which grow faster under higher, stable temperature. Moreover, the recovery period has allowed revealing post treatment effects (prolonged temperature effects) on species abundance, reflecting population changes due to individual life expectancy and reproductive rate.

\section{> REVISITING THE CONCEPT OF SPECIES OPTIMA}

The above results support the previously formulated hypothesis (Verbitsky and Verbitskaya, 2007; Verbitsky, 2008) that, in determining the ecological temperature optimum of a species 
Table II

Factor regimes and their characteristics.

Les différents régimes et leurs caractéristiques.

\begin{tabular}{|l|c|c|c|c|}
\cline { 3 - 5 } \multicolumn{1}{c|}{} & Constant ("static") & \multicolumn{3}{c|}{ Dynamic ("astatic") } \\
\cline { 3 - 5 } \multicolumn{1}{c|}{} & & Cyclic & Stepwise & Random \\
\hline Timing of change & $\mathrm{n} / \mathrm{a}$ & regular & irregular & random \\
\hline Direction & $\mathrm{n} / \mathrm{a}$ & alternative & variable & random \\
\hline Rate of change & $\mathrm{n} / \mathrm{a}$ & variable & fastest & variable \\
\hline Magnitude & fixed & variable & variable & variable \\
\hline Frequency & $\mathrm{n} / \mathrm{a}$ & regular & n/a & n/a \\
\hline Duration & infinite & none & variable & none \\
\hline Predictability & high & high & intermediate & none \\
\hline
\end{tabular}

n/a, not applicable.

within a natural community, it is not enough to define its optimum from constant, cyclic or random temperature changes, but also from unidirectional stepwise changes of temperature. We propose to draw a distinction between the concepts of "static" optimum (or static characteristics of an optimum) and "dynamic" optimum (or dynamic characteristics of an optimum) when defining an ecological optimum. The static optimum includes a range of optimum factors' values on tolerance scale and the "dose" of each factor corresponding to requirements of an organism and providing most favorable conditions for its life.

The dynamic optimum includes a set dynamic characteristics which provides optimum conditions for the life of an organism in natural habitats (or such conditions are necessary to be created in artificial habitats). At the time being, known dynamic characteristics include optimum parameters of periodic/cyclic changes of a factor (frequency and amplitude), their position within a range of optimum values (bottom, middle or top part), presence or absence of stimulating or inhibiting influence of stepwise changes of the factor, duration of influence of either "dose" of the factor, interval between values of "dose" and a directionality of a change of factor. Moreover, the presence and character of after-action (prolonged) effects, manifested some time after an action of optimal factor's values starts or even after it is terminated (delayed), should be taken into account (Figure 6).

Of course, the population dynamics of natural communities is also driven by other factors such as biotic interactions (e.g. Tilman et al., 1986), food availability (Starkweather and Bogdan, 1980; McCauley and Kalff, 1981; Stemberger, 1981; Pushchina and Verbitsky, 1983; Chow-Fraser and Knoechel, 1985; Chow-Fraser, 1986; Sarviro and Verbitsky, 1988; Zurek and Bucka, 1994) and fish predation (Brooks and Dodson, 1965; Verbitsky et al., 1980; Verbitsky and Verbitskaya, 1989; Cristoffersen et al., 1993; Ronneberger et al., 1993), as well as abiotic components such as turbidity (Zettler and Carter, 1986; Hart, 1988, 1990; Kirk and Gilbert, 1990; Kirk, 1991), nutrient status (Bays and Crisman, 1983; Hanson and Peters, 1983; Pace, 1986; Verbitsky and Verbitskaya, 2007).

But our researches of influence of others abiotic environmental factors (Verbitsky and Verbitskaya, 2007) and the analysis of the literature allows to assume, that the approach to define a real ecological optimum for ectotherms as described in this article may be applied to other environmental factors.

Table II summarizes the characteristics of the constant ("static") and dynamic ("astatic") factor regimes. The present study suggests that it is necessary to know the individual or species response to these different regimes in order to determine the biological optimum. The novel experimental design allowed demonstrating prolonged or delayed biological responses from the stepwise regime.

We assume that further investigations will reveal more characteristics and effects which directly determine a real ecological optimum in ectothermic animals, from which a more detailed concept of ecological optimum may arise. It also make it possible to estimate quantitatively 

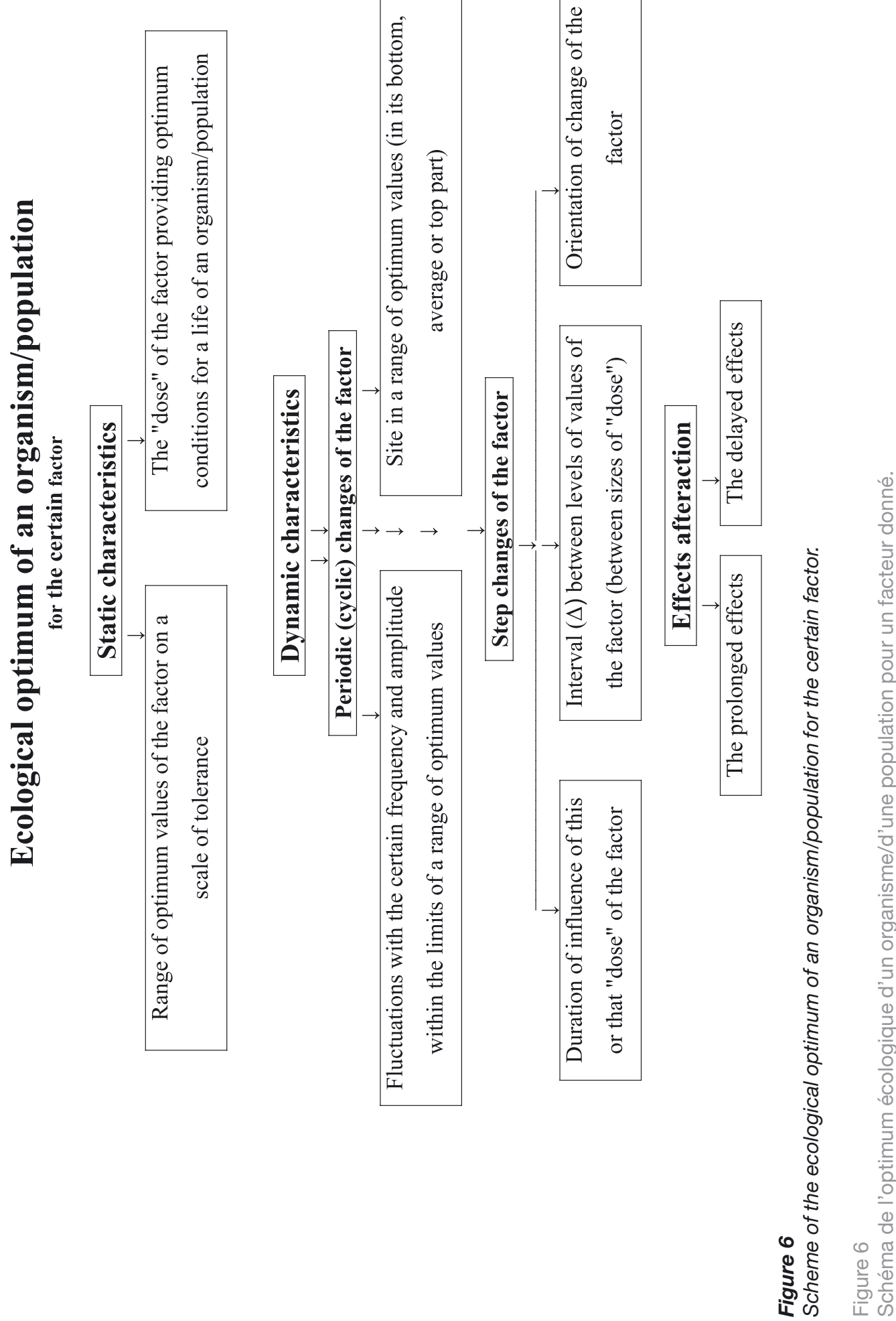
the contribution of various characteristics of environmental factors to formation of ecological optima for organisms and populations.

\section{> IMPLICATIONS FOR MANAGEMENT}

The approach outlined here, could be especially productive for an introduction of new species into aquaculture, as well as for optimization of cultivation regimes for aquatic and terrestrial ectothermic organisms.

Besides, this study provides critical evidence of Cladocera species response to the predicted increasing risks in sharp changes and extreme weather conditions due to climate change, as observed in summer 2010 in Russia, where the water temperature of the River Volga (Yaroslavl area, Gorki reservoirs) heated up to $29-30^{\circ} \mathrm{C}$ in July. Our experiments allow to make predictions regarding the single effect of temperature on Cladocera and probable consequences of such unexpected strong temperature impacts for water communities.

\section{CONCLUSIONS}

It is known that the response of species on temperature is largely determined by their environment. On the basis of the research carried out, it is shown for the first time, that increase in Cladocera abundance can be stimulated not only by warming up or rhythmic oscillatory modes, but also sustained unidirectional stepwise changes of temperature. Thus, the results of our study clearly illustrate distinctions in temperature ecological strategy of the studied species of Cladocera plankton, living in the same water reservoir.

These results support the previously formulated hypothesis that, in determining the ecological temperature optimum of a species within a natural community, it is not enough to define its optimum from constant or unidirectional temperature changes, but also from fluctuating step changes of temperature. Besides it is necessary to consider possible prolonged or delayed biological response to sudden stepwise changes in environmental conditions as expected under climate change.

\section{ACKNOWLEDGEMENTS}

We would like to thank two anonymous referees and Benoit Demars for their constructive comments and editorial improvements.

\section{REFERENCES}

Angilletta Jr. M.J., 2009. Thermal adaptation. A theoretical and empirical synthesis, Oxford University Press, Oxford.

Angilletta Jr. M.J., Niewiarowski P.H. and Navas C.A., 2002. The evolution of thermal physiology in ectotherms. J. Therm. Biol., 27, 249-268.

Balayla D.J. and Moss B., 2003. Spatial patterns and population dynamics of plant-associated microcrustacea (Cladocera) in an English shallow lake (Little Mere, Cheshire). Aquatic Ecol., 37, 417-435.

Barnes H. and Barnes M., 1969. Seasonal changes in the acutely determined oxygen consumption and effect of temperature for three common cirripedes, and Balanus balanoides (L.), B. balanus (L.) and Chthamalus stellatus (Poli). Journal of Experimental Marine Biology and Ecology, 4, 36-50.

Bays J.S. and Crisman T.L., 1983. Zooplankton and trophic state relationships in Florida lakes. Can. J. Fish. Aquat. Sci., 40, 1813-1819.

Behrens W., Hoffmann K.H., Kempa S., Gassler S. and Merkelwallner G., 1983. Effects of diurnal thermoperiods and quickly oscillating temperatures on the development and reproduction of crickets. Gryllus bimaculatus. Oecologia, 59, 279-287. 
Bertilsson J., Berzing B. and Pejler B., 1995. Occurrence of limnic micro-crustaceans in relation to temperature and oxygen. Hydrobiologia, 299, 163-167.

Bevan L., Wallen D.G. and Winner J.M., 1980. The effect of temperature, irradiance and animal size on incorporation rates of Simocephalus vetulus. Hydrobiologia, 69, 73-78.

Bottrell H.H., 1974. The relationship between temperature and duration of egg development in some epiphytic cladocera and copepoda from the River Thomez Reading, with a discussion of temperature functions. Oecologia, 18, 63-84.

Brooks J.L. and Dodson S.T., 1965. Predation, body size, and composition of the plankton. Science, 150, 29-35.

Chow-Fraser P., 1986. An empirical model to predict in situ grazing rates of Diaptomus minutus Lilleborg on small algal particles. Can. J. Fish. Aquat. Sci., 43, 1065-1070.

Chow-Fraser P. and Knoechel R., 1985. Factors regulating in situ filtering rates of Cladocera. Can. J. Fish. Aquat. Sci., 42, 567-576.

Costlow Jr. J.D., and Bookhout C.G., 1971. The effect of cyclic temperatures on larval development in the mud-crab Rhithropanopeus harrisii. In: Crisp D.J. (ed.), Fourth European Marine Biology Symposium, 211, Cambridge University Press, Cambridge.

Cristoffersen K., Riemann B., Klysner A. and Shindergaard M., 1993. Potential role of fish predation and natural populations of zooplankton in structuring a plankton community in eutrophic lake water. Limnol. Oceanogr., 38, 561-573.

Dajos R., 1975. Fundamentals of Ecology, Progress Publishers, Moscow, 415 p. [Dajos R., 1972. Précis d'Écologie, Gauthier-Villars, Paris] (in Russian).

Dent L. and Lutterschmidt W.I., 2003. Comparative thermal physiology of two sympatric sunfishes (Centrarchidae: Perciformes) with a discussion of microhabitat utilization. J. Therm. Biol. 28, 1, 67-74.

Dong Y., Dong S., Tiana X., Wanga F., Zhanga M., 2006. Effects of diel temperature fluctuations on growth, oxygen consumption and proximate body composition in the sea cucumber Apostichopus japonicus Selenka. Aquaculture, 255, 514-521.

Dong Y., Dong S. and Jia T., 2008. Effect of different thermal regimes on growth and physiological performance of the sea cucumber Apostichopus japonicus Selenka. Aquaculture, 275, 329-334.

Du W.-G., Lu Y.-W., Shu L. and Bao Y.-X., 2007. Thermal dependence of food assimilation and locomotor performance in juvenile blue-tailed skinks, Eumeces elegans. Anim. Biol., 57, 29-38.

Du W.-G., Shena J.-W. and Wanga L., 2009. Embryonic development rate and hatchling phenotypes in the Chinese three-keeled pond turtle (Chinemys reevesii): The influence of fluctuating temperature versus constant temperature. J. Therm. Biol., 34, 250-255.

Duigan C., 1992. The ecology and distribution of the littoral freshwater Chydoridae (Branchiopoda, Anomopoda) of Ireland, with taxonomic comments on some species. Hydrobiologia, 241, 1-70.

Eie J.A., 1974. A comparative study of the Crustacean communities in forest and mountain localities in the Vassfaret area (Southern Norway). Norw. J. Zool., 22, 177-205.

Elagina T.S., 1974. Effect of heated water discharge from the Kostroma thermal power plant on zooplankton of the Gorky reservoir. In: Proc. second symp. on the effect of thermal power plants on hydrologic and biological parameters of water bodies, Borok, 26-28.

Eubank W.P., Atmar J.W. and Ellington J.J., 1973. The significance and thermodynamics of fluctuating versus static thermal environments on Heliothis zea egg development rates. Environ. Entomol., 2, 491-498.

de Eyto E. and Irvin K., 2001. The response of three chydorid species to temperature, $\mathrm{pH}$ and food. Hydrobiologia, 459, 165-172.

Fisher J.R. and Edwards D.L., 2002. Temperature-dependent egg hatch and cold storage of eggs of Otiorhynchus ovatus (L.) (Coleoptera: Curculionidae). J. Agr. Urban Entomol., 19, 109-116.

Fryer G., 1968. Evolution and adaptive radiation in the Chydoridae (Crustacea: Cladocera): a study in comparative functional morphology and ecology. Phil. Trans. $R$ Soc. (B), 254, 221-385.

Fryer G., 1993. The Freshwater Crustacea of Yorkshire; a faunistic and ecological survey, Yorkshire Naturalists' Union \& Leeds Philosophical and Literary Society, 312 p.

Galkovskaja G.A., Mitjanina I.F. and Golovchits V.A., 1988. Ecology-biological basis of mass cultivation of Rotifera. Science and Technics, Minsk (in Russian). 
Gamperl A.K., Rodnick K.J., Faust H.A., Venn E.C., Bennett M.T., Crawshaw L.I., Keeley E.R., Powell M.S. and Li H.W., 2002. Metabolism, swimming performance, and tissue biochemistry of high desert redband trout (Oncorhynchus mykiss ssp.): evidence for phenotypic differences in physiological function. Physiol. Biochem. Zool., 75, 413-431.

Geraldes A.M. and Boavida M.J., 2004. What factors affect the pelagic Cladocerans of the mesoeutrophic Azibo reservoir? Ann. Limnol., 40, 101-111.

Giebelhausen B. and Lampert W., 2001. Temperature reaction norms of Daphnia magna: the effect of food concentration. Freshw. Biol., 46, 281-289.

Gorobey A.N., 1974. Transformation of zooplankton of Ivankovskoye reservoir in its circulation through the cooling system of Konakovskaya TPP. Influence of thermal power plants on the hydrology and biology of lakes. In: Proceedings of the Second Symposium, Borok, 26-28 August 31-34 (in Russian).

Gulyas P., 1980. The effect of temperature on the most frequent Cladocera and Copepoda species in lake Velenge. Aquacultura Hungaria, 2, 55-70.

Humpesch U.H., 1982. Effect of fluctuating temperature on the duration of embryonic development in two Ecdyonurus spp. and Rhithrogena cf. hybrida (Ephemeroptera) from Austrian streams. Oecologia, 55, 285-288.

Hanasato T. and Yasuno M., 1985. Effect of temperature in the laboratory studies on growth, egg development and first parturition of five species of Cladocera. Jpn. J. Limnol., 46, 185-191.

Hann B.J. and Zrum L., 1997. Littoral microcrustaceans (Cladocera, Copepoda) in a prairie coastal wetland: seasonal abundance and community structure. Hydrobiologia, 357, 37-52.

Hanson J.M. and Peters R.H., 1983. Empirical prediction of crustacean biomass and profundal macrobenthos biomass in lakes. Can. J. Fish. Aquat. Sci., 41, 439-445.

Hart R.C., 1988. Zooplankton feeding rates in relation to suspended solids content: potential influences on community structure in a turbid reservoir. Freshwater Biol., 19, 123-129.

Hart R.C., 1990. Zooplankton distribution in relation to turbidity and related environmental gradients in a large subtropical reservoir: patterns and implications. Freshwater Biol., 24, 241-263.

Havens K.E., 1991. Summer zooplankton dynamics in the limnetic and littoral zones of a humic acid lake. Hydrobiologia, 215, 21-29.

Hernandez M., Bückle L.F. and Espina S., 2002. Temperature preference and acclimation in Poecilia sphenops (Pisces, Poeciliidae). Aquac. Res., 33, 933-940.

Herzig A., 1984. Temperature and life strategies of Diaphanosoma brachyurum: an experimental study on development, growth and survival. Arch. Hydrobiol., 101, 143-178.

Hinz J. and Isquit J.R., 1974. The effect of thermal shocking on several strains of Blepharisma. J. Protozoology, 21, 416-417.

Hoelker F., 2003. The metabolic rate of roach in relation to body size and temperature. J. Fish Biol., 62, 565-579.

Hofmann W., 1996. Empirical relationships between cladoceran fauna and trophic state in thirteen northern German lakes: analysis of surficial sediments. Hydrobiologia, 318, 195-210.

Hutchinson G.E., 1957. Concluding remarks. Cold Spring Harbour Symposium on Quantitative Biology, 22, 415-427.

IUPS Thermal Commission, 2003. Glossary of terms for thermal physiology. Third Edition. J. Therm. Biol., 28, 75-106.

Joshi D.S., 1996. Effect of fluctuating and constant temperatures on development, adult longevity and fecundity in the mosquito Aedes krombeini. J. Therm. Biol., 21, 151-154.

Khan P.M., 1965. The effect of constant and varying temperatures on the development of Acanthocyclops viridis (Jurine). Proc. Roy. Trish. Acad. Ser. B, 64, 117-130.

Kirk K.L., 1991. Inorganic particles alter competition in grazing plankton: the role of selective feeding. Ecology, 72, 915-923.

Kirk K.L. and Gilbert J.J., 1990. Suspended clay and the population dynamics of planktonic rotifers and cladocerans. Ecology, 71, 1741-1755.

Kiselyov I.A., 1969. Plankton of the seas and continental waterbodies, Vol. 1: Science, Leningrad, 657 p. (in Russian). 
Konstantinov A.S., 1993. Effect of temperature fluctuations on growth, energy and physiological state of young fish. Proceedings of the Russian Academy of Sciences. Ser. Biol, 1, 55-63 (in Russian).

Konstantinov A.S., Vechkanov B.C., Kuznetsov V.A. and Ruchin A.B., 2000. Astatic abiotic environment as a condition for optimizing the growth and development of larvae of common frog Rana temporaria L. Proceedings of the Russian Academy of Sciences, 371, 559-562 (in Russian).

Kreutzer C. and Lampert W., 1999. Exploitative competition in differently sized Daphnia species: A mecharistic explanation. Ecology, 80, 2348-2357.

LaBerge S. and Hann B.J., 1990. Acute temperature and oxygen stress among genotypes of Daphnia pulex and Simocephalus vetulus (Cladocera, Daphniidae) in relation to environmental conditions, Can. J. Zool., 68, 11, 2257-2263.

Loiterton B., Sundbom M. and Vrede T., 2004. Separating physical and physiological effects of temperature on zooplankton feeding rate. Aquat. Sci., 66, 123-129.

Luferova L.A. and Monakov A.V., 1966. Zooplankton of the Rybinsk Reservoir in 1956-1963 yy. In: Plankton and benthos of inland waters, Leningrad, 40-55 (in Russian).

Manca M. and Comoli P., 1999. Studies on zooplankton of Lago Paione Superiore. J. Limnol., 58, 131135.

Manca M., De Bernardi R. and Savia A., 1986. Effects of fluctuating temperature and light conditions on the population dynamics and the life strategies of migrating and nonmigrating Daphnia species. Mem. Ist. Ital. Idrobiol., 44, 177-202.

McCauley E. and Kalff J., 1981. Empirical relationships between phytoplankton and zooplankton biomass in lakes. Can. J. Fish. Aquat. Sci., 38, 458-463.

McKee D., Atkinson D., Collings S.E., Eaton J.W., Gill A.B., Harvey I., Hatton K., Heyes T., Wilson D. and Moss B., 2003. Response of freshwater microcosm communities to nutrients, fish, and elevated temperature during winter and summer. Limnol. Oceanogr., 48, 707-722.

Melanie J.E. and Shine R., 1999. Sex differences in optimal incubation temperatures in a scincid lizard species. Oecologia, 118, 431-437.

Merkel G., 1977. The effects of temperature and food quality on the development of Gryllus bimaculatus (Orthoptera, Gryllidae). Oecologia, 30, 129-140.

Meyers D.G., 1984. Egg development of a chydorid cladoceran, Chydorus sphaericus, exposed to constant and alternating temperatures - Significance to secondary productivity in fresh waters. Ecology, 65, 309-320.

Mezquita F. and Miracle M.R., 1997. Chydorid assemblages in the sedimentary sequence of Lake La Cruz (Spain), subject to water level changes. Hydrobiologia, 360, 277-285.

Novingera D.C. and Coon Th.G., 2000. Behavior and physiology of the redside dace, Clinostomus elongatus, a threatened species in Michigan. Env. Biol. Fish., 57, 315-326.

Odum E.P., 1971. Fundamentals of Ecology, W.B. Saunders Company, Philadelphia-London-Toronto, $740 \mathrm{p}$.

Orcutt J.D. and Porter K.G., 1983. Diel vertical migration by zooplankton: constant and fluctuating temperature effects on life history parameters of Daphnia. Limnol. Oceanogr., 28, 720-730.

Pace M.L., 1986. An empirical analysis of zooplankton community size structure across lake trophic gradients. Limnol. Oceanogr., 31, 45-55.

Perrow M.R., Jowitt A.J.D., Stansfield J.H. and Phillips G.L., 1999. The practical importance of the interactions between fish, zooplankton and macrophytes in shallow restoration. Hydrobiologia, 395/396, 199-210.

Poff N.L. and Zimmerman J.K.H., 2010. Ecological responses to altered flow regimes: a literature review to inform the science and management of environmental flows. Freshwater Biology, 55, 194-205.

Prosser L. and Brown F., 1967. Comparison physiological of animals, Mir, Moscow, 766 p. (in Russian).

Pushchina L.I. and Verbitsky V.B., 1983. About interrelation of a vegetative and animal plankton of ponds for cultivation of young fishes. Ground and water ecosystems, Gorky, 109-117 (in Russian).

Ranta E. and Tjossem S., 1987. Size and shape of Daphnia longispina in rock-pools. Hydrobiologia, 145, 259-268.

Rivjer I.K., 1986. Composition and ecology of zooplankton communities in the winter, Leningrad, Moscow, 160 p. (in Russian). 
Rivier I.K., 1992. Ecology of Cladocera in winter water bodies. In: Current problems in the study of Cladocera, Gidrometeoizdat, St. Petersburg, 65-80 (in Russian).

Rodnick K.J., Gamperl A.K., Lizars K.R., Bennett M.T., Rausch R.N. and Keeley E.R., 2004. Thermal tolerance and metabolic physiology among redband trout populations in south-eastern Oregon. J. Fish Biol., 64, 310-335.

Ronneberger D., Kasprzak P. and Krienitz L., 1993. Long-term changes in the rotifer fauna after biomanipulation in Hausee and its relationship to the crustacean and phytoplankton community. Hydrobiologia, 255/256, 297-340.

Sarviro V.S., 1985. Temperature dependence of developmental period and specific growth rate of immature female Daphnia longispina O.F. Müller (Crustacea, Cladocera) in enclosure experiments, Gidrobiol. Zh., 21, 28-33.

Sarviro V.S. and Verbitsky V.B., 1988. Food selectivity of planktonic filtration organisms in a flowing gradient of forages. II. Food selectivity of Bosmina longirostris O.F. Müller. Biology of Internal Waters. The Information Bulletin, 80, 50-53 (in Russian).

Schmidt G.H., 1981. Growth and behaviour of Aerotylus patruelis (H. S.) larvae in temperature gradients under laboratory conditions. Zool. Anz., 206, 1125-1129.

Semenchenko V.P., Razlutskii V.I. and Feneva I.Yu., 2005. Biotic interactions as a factor influencing the success of the invasion of Cladocerans into aquatic communities. In: Alien Species in Holarctic (Borok_2), Abstr. Second Int. Symp. on Studying Invasive Species), Rybinsk, 116-117 (in Russian).

Semenchenko V.P., Razlutskii V.I., Feneva I.Yu. and Aibulatov D.N., 2007. Biotic relations affecting species structure in zooplankton communities. Hydrobiologia, 579, 219-231.

Sharitz R.R. and Luvall J.C., 1978. Growth of duckweed under constant and variable temperatures, in energy and environmental stress in aquatic systems, DOE Symp. Ser. (CONF-77I114). In: Thorp J.H. and Gibbons J.W. (eds.), Springfield, VA, Natl. Techn. Inf. Service.

Shelford V.E., 1927. An experimental investigation of the relations of the codling moth to weather and climate. Bull. Illinois Nat. Hist. Survey, 16, 307-440.

Schiel D.R., Steinbeck J.R. and Foster M.S., 2004. Ten years of induced ocean warming causes comprehensive changes in marine benthic communities. Ecology, 85, 1833-1839.

Stansfield J.H., Perrow M.R., Tench L.D., Jowitt A.J.D. and Taylor A.A.L., 1997. Submerged macrophytes as refuges for grazing Cladocera against fish predation: observations on seasonal changes in relation to macrophyte cover and predation pressure. Hydrobiologia, 342/343, 229-240.

Starkweather P.L. and Bogdan K.G., 1980. Detrital feeding in natural zooplankton communities: discrimination between live and dead algal foods. Hydrobiologia, 73, 83-85.

Stemberger R.S., 1981. A general approach to the culture of planktonic rotifers. Can. J. Fish. Aquat. Sci., 38, 721-724.

Sushchenja L.M., 1978. Growth of animals under oscillating temperature conditions. In: Elements of water ecosystems, Works VGBO, 22, 140-150 (in Russian).

Svirskiy A.M. and Valtonen T., 2002. A daily rhythm of thermoregulation behaviour of juvenile muksun, Coregonus muksun. Problems of Ichthyology, 42, 811-819 (in Russian).

Sweeney B.W. and Schnack J.A., 1977. Egg development, growth, and metabolism of Sigara alternata (Say) (Hemiptera: Corixidae) in fluctuating thermal environments. Ecology, 58, 265-277.

Thorp J.H. and Hoss D.E., 1975. Effects of salinity and cyclic temperature on survival of two sympatric species of grass shrimp (Palaemoneies), and their relationship to natural distributions. J. Exp. Mar. Biol. Ecol., 18, 19-28.

Thorp J.H. and Wineriter S.A., 1981. Stress and growth response of juvenile crayfish to rhythmic and arrhythmic temperature fluctuations. Arch. Environm. Contam. Toxicol., 10, 69-77.

Tilman D., Kiesling R., Sterner R., Kilham S.S. and Johnson F.A., 1986. Green, blue green and diatom algae - taxonomic differences in competitive ability for phosphorus, silicon and nitrogen. Archiv für Hydrobiologie, 106, 473-485.

Van Doorslaer W., Stocks R., Jeppensen E. and Meester L., 2007. Adaptive microevolutionary responses to simulated global warming in Simocephalus vetulus: a mesocosm study. Global Change Biology, 13, 878-886.

Velichko A.N., 1982. Effect of heating on the production of mass species of cladocerans from Ivankovskoye reservoir, Ecology of aquatic organisms of Upper Volga reservoirs, Leningrad, 123-143 (in Russian). 
Verbitsky V.B., Pivakovskaja I.V. and Mjagkova G.N., 1980. About interrelation of a feed of young carps of the first year with development of a natural forage reserve of ponds. In: Problems of protection of waters and fish resources of the Volga region, Kazan, 101-103 (in Russian).

Verbitsky V.B. and Verbitskaya T.I., 1989. Efficiency of use Bosmina longirostris O.F. Müller as a starting alive forage for yang fishes. Biol. Internal Waters. Inform. Bull., 86, 41-44 (in Russian).

Verbitsky V.B., Verbitskaya T.I. and Golovanova E.V., 2002. The critical temperature maximum for Daphnia longispina (O.F. Müller, 1785) (Crustacea: Cladocera) under natural conditions and in experiment. Biol. Inl. Water, 4, 45-50 (in Russian).

Verbitsky V.B. and Verbitskaya T.I., 2007. Ecological optimum and effect of delayed action of a factor. Doklady Biological Sciences, 416, 386-388.

Verbitsky V.B., 2008. The notion of ecological optimum and its determination in freshwater poikilothermic animals. Journal of General Biology, 69, 44-56 (in Russian).

Whiteside M.C., 1970. Danish chydorid Cladocera: modern ecology and core studies. Ecol. Monogr., 40, 79-118.

Whiteside M.C. and Harmsworth R.V., 1967. Species diversity in chydorid (Cladocera) communities. Ecology, 48, 664-667.

Zettler E.R. and Carter J.C.H., 1986. Zooplankton community and species responses to a natural turbidity gradient in Lake Temiskaming, Ontario-Quebec. Can. J. Fish. Aquat. Sci., 43, 665-673.

Zurek R. and Bucka H., 1994. Algal size classes and phytoplankton-zooplankton interacting effects. J. Plankton Res., 10, 583-601. 